\title{
Through a Glass, Darkly: Jean Baudrillard and the Mirror of Critical Theory
}

\author{
Graham Mackenzie
}

According to Jean Baudrillard (1975), Karl Marx's critique of political economy "assists in the cunning of capital" (31). In other words, Marxism, in this account, is a particularly duplicitous variant of capitalist ideology. This is a rather damning assertion to level against a critical theory that sees the analysis and overcoming of capitalism as its guiding historical objective. Moreover, it is an assertion with decidedly far-reaching implications. For if Baudrillard's critique of Marx is well-founded, then the claims of many post-structuralists, post-Marxists, post-colonialists and post-modern thinkers who counsel a relegation of the Marxian project to the dustbin of history (either overtly or tacitly) are also legitimate; thus Marxism, in this account, can be considered, at best, a dead ideology, a spent historical force - at worst, it is a misdirection of the emancipatory energy of those on the left who subscribe to a Marx-inspired critical theory, a misdirection that renders them complicit in the very thing they seek to overcome. As such, insofar as the Marxist critique of political economy is irredeemably bound to the capitalist mode of production in such a way that it actually operates in collusion with the continuing reproduction of the social configuration it seeks to abolish - and this is Baudrillard's position from roughly 1973 onward[1] - then perhaps the best course of action for those interested in the critique of contemporary forms of domination and exploitation is a strict adherence to an on-going silence where Marxism is concerned, such that Marx's socio-political project (and attendant Marxist discourses) might finally be left to rest in peace. Perhaps this is so.

Or perhaps there is life yet in the Marxian project. Perhaps it is "high time that [Marxist critical theorists] should openly, in the face of the whole world [of academic criticism], [rearticulate] their views, their aims, their tendencies, [redouble their critical-political efforts], and meet this nursery tale of the Spectre of [Marxian capitalism] with a [critique of the condition of post-Marxism itself]" (Marx and Engels 1978: 473).[2] For while critical approaches to Marxist thought, such as Baudrillard's The Mirror of Production, appear rather damning, I would like to suggest that this appearance is grounded in a misunderstanding of Marx's methodological developments spanning over the course of his writing career. In other words, Baudrillard's critique of Marxist political thought is, I contend, a critique of received interpretations of Marx from mainly the 1960's and 70's - Baudrillard thus reads Marx through the lens of the disappointments of the Paris Spring of 1968, that is, 'through a glass, darkly' (1 Corinthians 13: 12).

Far from grasping the essential thrust of Marx's mature critical theory of capitalist social formations, Baudrillard (1975) reads into Marx some of the most problematic metaphysical assumptions of the modern epoch, "the metaphysics of the market economy in general and [of] modern capitalist ideology in particular" (59). He then proceeds to burn this straw person to the ground. His critique is thus a project that turns, essentially, on methodological questions. For it rests upon a reading of Marx that misapprehends historical materialism, fails to grasp the abstract-concrete relation in Marx's work, and misconstrues dialectics for an antagonistic and jagged but essentially linear chain of causality, all of which can be summed up, in Baudrillard's terms, under the rubric of 'productivist ideology'[3]. It should be noted, however, that I do not mean to argue that Baudrillard has merely fabricated the object(s) of his critique. All too often, those writing under the banner of Marxist theory have subscribed to positions and methodological assumptions located well within the blast radius of Baudrillard's commentary. 


\section{Baudrillard's Conservative Radicalism}

But this has led commentators such as Gerry Coulter (2011) to claim that “if we take Baudrillard's understanding of Marx to its logical conclusions - we can provocatively say that the left was never really anything more than a prosthesis of the right." This position is, I think, something of an overstatement - not all of Marx's interpreters, to say nothing of Marx himself, fall victim to the assumptions against which Baudrillard sets his critique. Moreover, even if we are willing to abide this brand of blanket cynicism for the moment and marginalize the struggles of those who have worked, often in the service of real socio-political gains, against the hegemony and/or social domination of capital, it seems fair to say that Baudrillard collapses Marx's writings into a set of historically circumscribed representations popular amongst some Marxists during the middle third of the 20th century, representations which he summarily dismisses as obsolete[4]: in his own words, "the work of the negative, the work of critical thought, of the relationship of forces against oppression, or of radical subjectivity against alienation, all this has (virtually) become obsolete" (Baudrillard 2010: 36). As such, Baudrillard's apparent [5] willingness to dispense, almost entirely, with the Marxian critical perspective and methodology bespeaks a tendency toward a conservative and cynical political/theoretical nihilism that despairs of the possibility of effective counter-hegemonic praxis and hence does away with the responsibility to critically engage with the capitalist social formation - and it does so in the name of radical critique.

Yet, even if this sort of approach is radically critical it nevertheless leads to a position that is, at the same time, radically disempowering. As Wendy Brown (1995) points out "the very meaning of radical critique is transformed when there is no historical prospect of redressing the critique, when there is no social dynamic, and when the power deployed by the dominant class [or system] is not retrievable by the subordinate class" (93).[6] 'Radical critique', in Baudrillard's hands, thus becomes the (ineffectual) ritual play of a kind of modern Cassandrian theoretical sect, destined to 'know' our unpleasant social destinies but never to be taken seriously or, at any rate, sufficiently grasped by anyone with the power or will to make a difference. In other words, Baudrillard replaces the Marxian project "with a form of semiological idealism and technological determinism where signs and objects come to dominate the subject" (Kellner 2006); this is what Baudrillard would come to theorize as simulacra. Indeed, as some theorists have pointed out, Baudrillard's account of 'the simulacra' has "a very high degree of descriptive power" (Dyer-Witheford 1999: 176). For, as Nick Dyer-Witheford (1999) explains, "[the simulacra] registers a situation in which control of the media often (if not as uniformly as he suggests) gives established power the capacity not just to promulgate specific beliefs and values, but to set the very parameters of perception" (176).

Nevertheless, this is a form of idealism, a contemplative reflection, a mirror of critical theory; it is what Theodor Adorno (1984) referred to as an illusion of the concrete which "rests on the reification of results" (37). [7] In other words, Baudrillard seems to naturalize the contemporary situation, even as he claims that the contemporary power of the media, of sign economies, is historically unprecedented; this constitutes a variation on the imperialism of Hegelian historicism, an imperialism in which all that has gone before is teleologically annexed to the present. [8] In this way, as a consequence of the idealism of his theory, Baudrillard's social critique founders against the impassable reef of his merely contemplative/speculative stance. Incidentally, Michel Foucault (2010) once remarked that it is all too easy to overlook our proximity to Hegel, and hence his influence on our thinking; Baudrillard often seems unaware of the idealist and conservative implications in his work, of the way that he makes the present into the final stage of history - in short, he seems unaware of "the extent to which Hegel, insidiously perhaps, is close to [him]" (235).

It is perhaps not surprising, then, that Arthur Kroker (1985) should characterize Baudrillard as a tragic figure radically transgressive in aspiration and conservative in fact (70). [9] This is closely related to Baudrillard's willingness, in the end, to jettison the analysis of capital. In other words, owing to his position that capitalism (as Marx understood it) has already been overtaken and replaced with a vast and impenetrable system of signs, Baudrillard ends up occupying a deeply pessimistic theoretical position with respect to his prognosis for a change in the contemporary mode of production. His claim that we have moved beyond anything that Marx himself might have recognized as capitalism leads him at once to say that class conflict and social contradiction are no longer centrally or even peripherally relevant,[10] that critical theory is now a useless sham,[11] and that we must try, insofar as this is even possible, to pass through the illusory materiality of the present which, in Baudrillard's account, is really all that remains of capitalism.[12] 


\section{| Misappropriating Marxist Critical Theory}

So far, I have gestured toward what I see as some of the central problems of Baudrillard's reading of Marx's critical theory. I have suggested that Baudrillard sees Marx's critical theory as historically relative. That is, Marx's reading of the capitalist social formation, for Baudrillard, suggests that "capital (its historical function) produces the social" (Coulter 2011) and along with it, the critique of that social form. As a general formula, this claim is not, on its own, overly problematic - it corresponds roughly to the idea that the capitalist bourgeoisie produces its own gravediggers (Marx \& Engels 1978: 483). However, Baudrillard's related claim, which is to suggest that we have left the productive form of capitalism behind and entered a new stage of history,[13] engenders a 'critical' position which asserts, at base, that since Marx's critical theory was adequate only to the 'era of production', it is no longer relevant or, properly speaking, critical.[14] A corollary of this assertion is that Marxist analysis thereby misapprehends the contemporary social configuration and hence serves to mask the actual conditions of social domination at work in the present. Insofar as Marxism operates in this fashion, it serves to redirect critical focus away from contemporary techniques of domination, perfected, in Baudrillard's (1983) estimation, in the movement "from capitalist-productivist society to a neo-capitalist cybernetic order that aims now at total control" (111), leaving these new techniques free to pursue their own logic - that of a total and culminating internalized dominion, hegemony in Baudrillard's terminology.[15] This idea, the idea that Marxism not only succumbs to productivist ideology, but constitutes, aids and abets it, describes, in a general form, the essence of Baudrillard's critique of Marxism as well as the general problems endemic to his critical approach.

If one of the strengths of Baudrillard's reading of Marx is his emphasis on sign systems, his related eagerness to proclaim the death of the system of commodity production is perhaps one of its most puzzling aspects.[16] Indeed, according to David Harvey (1989), Baudrillard's recognition of the increasing importance of sign-economies leads him "to argue that Marx's analysis of commodity production is outdated," (289) as we have already seen, because for Baudrillard, "capitalism is now predominantly concerned with the production of signs, images, and sign systems rather than with commodities themselves" (289). But as Harvey (1989) goes on to argue, "The transition he points to is important, though there are in fact no serious difficulties in extending Marx's theory of commodity production to cope with it" (289). If this is so, why then does Baudrillard insist that Marxist critical theory is now extraneous to contemporary existence?

The answer lies in Baudrillard's misapprehension of the key elements of Marx's methodological approach, as well as his misapprehension of the manner in which Marx deploys those elements. To begin with, Baudrillard's apprehension of dialectics corresponds more to what might be described as reductionist Marxist ideology than to Marx's actual analytical methodology. According to Baudrillard (1981b), dialectical analysis, "the general form of Marxist analysis," follows the procedure, at the social level, of an articulation and (predicted) resolution of "contradictions between forces and relations of production" (164), between productive labour and private property. To be sure, many have taken this formula to be one of Marx's key contributions to critical socio-political analysis. But rendered in this (reductionist) way, the essence of Marx's approach to the critique of political economy appears to be bound to idea that the characteristics that best define capitalism are the following: "class relations structured by a market economy and private ownership of the means of production" (Postone 1998: 49). These relations are understood to be relations of domination grasped primarily "in terms of class domination and exploitation" (Postone 1998: 49). And these relations are, furthermore, understood to be in contradiction with the forces of industrial production. In other words, as Baudrillard understands it, the essence of Marx's analysis is that the relations of production - private property and the market - constitute the essential form of capitalist domination exercised over the forces of production - understood as industrial labour/production - which are posited as the basis of the liberating potential intrinsic to the capitalist mode of production. But in this account of Marx's analysis, the idea of an intrinsic (immanent) dialectical contradiction is grounded, in fact, in a transcendental category - industrial labour as the 'true producer' of social wealth hidden beneath the 'false' social relations of market mediated private property. Baudrillard thus renders Marx a 'socialist Ricardian', which according to Stuart Hall (2003) entails believing that "since labour [is] the source of all value, all men should become labourers exchanging equivalent amounts of labour" (144).

What this reading of Marx fails to grasp is the radically immanent nature of his use of the dialectic. Marx is not simply suggesting that there is an empirically immanent class/group in capitalist society whose interests, if emancipated, would change the essence (deep structures) of capitalism via a change at the surface level of structures 
of accumulation (distribution). This approach would merely set antagonistic classes next to one another and assert that a historical dynamic will emerge - this would be Kant's position, grounded in human striving toward universal morality. It is, in other words, a variant of positivism/idealism. As Hall (2003) points out, "the method which merely sets opposites together in an external way, which assumes that, because things are neighbours, they must therefore be related, but which cannot move from oppositions to contradictions, is 'dialectical' only in its surface form" (120). Nevertheless, Baudrillard appears to mistake precisely this type of positivist/idealist (or rather, 'metaphysical' - due to the fact that it attributes unobserved political tendencies such as a tendency toward overcoming antinomies to this opposition) antinomy, for the dialectical method of analysis at work in Marx's critique. Moishe Postone (1996), conversely, points out that Marx's use of the dialectic posits contradiction at the cellular level of social organization; dialectical contradiction "should not be understood simply as a social antagonism between laboring and expropriating classes" (88). For, again, this would simply appeal to a metaphysics of wealth production (grounded in a humanist concept of labour) fused together with a positivist sociology of class antagonism (as opposed to dynamic contradiction) - exactly the charge that Baudrillard levels against Marxism in order to substantiate the claim of its complicity with the prevailing state of affairs. Rather, "social contradiction refers to the very fabric of a society, to a self-generating 'nonidentity' intrinsic to its structures of social relations - which do not, therefore, constitute a stable unitary whole" (Postone 1996: 88).[17] As such, Baudrillard's insistence on a superficial and metaphysical reading of Marx's use of dialectical method leads him into a whole host of misinterpretations.

For example, because Baudrillard grasps the Marxian dialectic as a metaphysical (and Manichean) antagonism between the abstract and the concrete, wherein the concrete side of the dialectic is apprehended as that which is legitimately 'human', he builds a critique of Marx's concept of use-value that is inadequate to Marx's critical theory. Baudrillard (1981a) begins his critique of use-value with the claim that "to be sure, there could be no exchange value without use value - the two are coupled" (130); however, he goes on to say that "neither is strongly implied by the other" (130). He then argues that contrary to the supposedly concrete category of use value in Marx's analysis, use value is actually both abstract and an aspect of capitalist rationalization (and hence domination). In fact, Baudrillard's critique of the category of use value is close to Marx's own, notwithstanding Baudrillard's misrepresentation of Marx's position. Moishe Postone (1980) characterizes this common misinterpretation (a misinterpretation which is also Baudrillard's) of Marx's concept of the fetish character of capitalist social relations as follows: One aspect of the fetish, then, is that capitalist social relations do not appear as such and, moreover, present themselves
antinomically, as the opposition of the abstract and concrete. Because, additionally, both sides of the antinomy are
objectified, each appears to be quasi-natural: the abstract dimension appears in the form of "objective," "natural" laws; the
concrete dimension appears as pure "thingly" nature. ... Forms of anti-capitalist thought which remain bound within the
immediacy of this antinomy tend to perceive capitalism, and that which is specific to that social formation, only in terms of
the manifestations of the abstract dimension of the antimony. The existent concrete dimension is then positively opposed
to it as the "natural" or ontologically human, which stands outside of the specificity of capitalist society. Thus, as with
Proudhon, for example, concrete labour is understood as the non-capitalist moment which is opposed to the abstractness
of money. That concrete labour itself incorporates and is materially formed by capitalist social relations is not understood
$(109-110)$.

As such, when Baudrillard argues that "the same logic (and the same fetishism) plays on the two sides of the commodity specified by Marx: use value and exchange value" (Baudrillard 1981a: 134) he is in effect arguing in concert with Marx himself.

However, when he accuses Marx of "not submitting use value to this [commodity] logic of equivalence in radical fashion, [and of] maintaining use value as the category of 'incomparability"' (Baudrillard 1981a: 134), he has misread Marx in just the way that Postone suggests is characteristic of 'forms of anti-capitalist thought which remain bound within the immediacy of the antinomy of capitalist social relations.' Furthermore, when Baudrillard (1981a) claims, on the basis of this misreading, that Marx contributes "to the mythology (a veritable rationalist mystique) that allows the relation of the individual to objects conceived as use values to pass for a concrete and objective - in sum, 'natural' - relation between man's needs and the function proper to the object' (134) he mischaracterizes Marx's argument. Marx does not hold that objects conceived as use values in capitalist social relations are in concrete relation to the needs of a transcendental human subject. Just as with production and consumption, use value and exchange value, under the capitalist mode of production, mediate one another: "The mediation is teleological. Each ... finds its end in the other" (Hall 2003: 122-123). And lastly, when Baudrillard (1981a) claims that "this is all seen as the opposite of the abstract, reified "alienated" relation the subject would have toward products as exchange values" (134), he reveals the ideological nature of his polemic via his clear misreading of Marx's categories. In other words, 
Baudrillard reads Marx as maintaining the position that, in fact, Marx criticized. Baudrillard then proceeds to occupy Marx's actual theoretical position - that the manifestation of the commodity fetish, made up of concrete use value and abstract exchange value, is a function of ideology - only to then declare Marxism obsolete. Since Marxism, whatever else it may be, is one of the signifiers commonly associated with the critique of capitalism, Baudrillard in effect delegitimizes the critique of capitalist domination by calling into question the existence of capitalism as it is represented according to his own, though not according to Marx's actual rendering of the critique of political economy.

Finally, Baudrillard's misinterpretation of Marx can be attributed, as I have suggested, to the metaphysical nature of the concepts that he himself ascribes to Marx's analysis. In other words, Baudrillard's determination to find metaphysical assumptions in the Marxian analysis of capitalism only serves to indicate that he has failed to grasp the role that historical materialism plays as a methodological precept in Marx's critical theory. For Baudrillard (1975), a central problem of historical materialism is that, in his estimation, it bases "the intelligibility of the contradictions of political economy on the structural givens of the finished system (capital)" (65). Here Baudrillard interprets Marxism credibly, if in my view incorrectly, as a kind of historicist approach to social dynamics. There are at least two possible responses to this.

First, Slavoj Žižek, leaning towards Hegel in his interpretation of history, argues that it is not that Marxist political economy "projects itself retrospectively" (Baudrillard 1975: 66) onto all other forms of society and then posits a logical progression from one successive stage of history to the next, but rather that "all civilized societies were class societies, but prior to capitalism, their class structure was distorted by a network of other hierarchical orders (castes, estates, and so forth) - only with capitalism, when individuals are formally free and equal, deprived of all traditional hierarchical links, does the class structure appear 'as such"' (Žižek 2010: 196). Despite appearances, Žižek claims that this is not a teleological argument. Instead, his argument works retroactively such that "once capitalism arrives (emerging in a wholly contingent way), it provides a universal key for all other formations” (197). Theoretically, this argument can answer a number of objections to traditional Marxist views such as critiques of Marxist history that claim he is committed to a kind of teleological causality. Also, it is wholly consistent with Baudrillard's (1975) characterization of Marxist historical materialism as "the projection of the class struggle and the mode of production onto all previous history" (67). However, it is difficult to see what methodological role this model can play other than to colonize all of history according to the dictates of the present. For Baudrillard (1975) - and here I am inclined to agree - this rendering of history, a kind of 'coming to historical consciousness', is closely related to "the vision of a future 'freedom' based on the conscious domination of nature" (67). If this is true then we would appear to have bought into precisely the kind of metaphysics of the subject/object that Baudrillard critiques, a metaphysics of history grounded in the productivity of 'concrete labour', a productivity that has been consistently exploited at the distributive level of the relations of production.

However, Moishe Postone (1996) offers another possible response to Baudrillard's objection to Marx's historical method. Postone's view is that Marx's critique of capitalism involves a "historically specific social explanation of the existence of a historical logic" (258); the historical specificity of Postone's reading of Marx's critical theory "rejects any notion of an immanent logic of human history as yet another projection onto history in general of capitalist society's conditions" (258), conditions beholden to bourgeois humanist metaphysics, for example. This reading of Marx's historical materialism also avoids the productivism that Baudrillard goes to such lengths to attribute to Marx by grounding that productivism in the structures of capitalism as a historically circumscribed mode of social organization and production. As such, the productivism that Baudrillard attributes to Marx is, in this account, an element of the object of Marx's critique - of bourgeois political economy. Likewise, Postone's rendering of historical materialism avoids a teleological metaphysics of human history, writ large, while still retaining the ability to explain the dynamics of capitalist history.

\footnotetext{
The idea that an immanent historical logic characterizes capitalism but not all of human history opposes any conception of a unitary mode of historical development. Yet such a notion does not imply an abstract form of relativism. Although the rise of capitalism in Western Europe may have been a contingent development, the consolidation of the commodity form is a global process, mediated by a world market that becomes increasingly integrated in the course of capitalist development. This process entails the constitution of world history. Thus, according to such an approach, a universal process with an immanent logic of development that provides the standpoint of a general critique does exist; it is historically determinate, however, and not transhistorical (Postone 1996: 258).
}

Finally, because Postone renders Marx's historical materialism as a critique of a historically determinate form 
of social organization, Baudrillard's (1975) claim that Marx's critique of labour in capitalism “produces the universal abstraction of the concept of labour and the retrospective illusion of the validity of this concept for all societies" (85) ceases to appear as a problem of the Marxian analysis. It can instead be explained with reference to the fetishization of the categories of the abstract and concrete, a fetishization that emerges on the basis of social organizations arising with a mode of social production whose essence is the commodity form.

\section{Conclusion: Pace Baudrillard}

In sum, Jean Baudrillard makes a number of salient critiques of what can be termed Marxist ideologies. And while he articulates important criticisms of Marx's categories that could serve as useful correctives and reinterpretations of the way that Marx's texts, concepts, categories, and methodological commitments have often been read, he nevertheless misrepresents Marx's texts themselves. As such, he abandons the project of articulating a revitalised critical theory of the capitalist social form and thereby often retreats to a pre-Marxist critical position - a pale reflection of the robustness of the Marxian critical method. Proclaiming the end of the dominance of the commodity while simultaneously denouncing the excesses of the contemporary consumer society in which we find ourselves today, a society which is no less subject to the whims of capital than when Marx was writing, Baudrillard appears to be trapped amongst the reflections and projections of his own errors of interpretation. In that sense, Baudrillard's social critique expresses itself in an idiom that is at best merely outdated, at worst, where Marxist analysis is concerned, he is speaking a language that is all his own. And if we recall that the Greek word idion referred to what was one's own, then where Baudrillard's critique of Marx is concerned we might say the following: "it is a tale told by an idiot, full of sound and fury, signifying nothing" (Shakespeare 1993: 1. 27-29, Scene 5, Act 5).

\section{References}

1. According to Douglas Kellner (n.d.), "in his first three books, Baudrillard argued that the classical Marxian critique of political economy needed to be supplemented by semiological theories of the sign. His argument was ... that the transition from the earlier stage of competitive market capitalism to the stage of monopoly capitalism required increased attention to demand management, to augmenting and steering consumption." However, if Baudrillard's early work moved in the universe of Marxian critique, by the mid 1970's he declares “the end of political economy and thus the end of the Marxist problematic and of modernity itself" (Kellner 2006; Baudrillard 1975).

2. I am playing with Marx's language here. The original quotation reads as follows: "It is high time that Communists should openly, in the face of the whole world, publish their views, their aims, their tendencies, and meet this nursery tale of the Spectre of Communism with a manifesto of the party itself." In addition, the kind of project I am suggesting is by no means original and is well under way. Post-modernism and its by-products - post-structuralism, post-Marxism, post-colonialism, etc. - have come in for criticism from a number of scholars such as Douglas Kellner, David Harvey, Frederic Jameson, Terry Eagleton, Stuart Hall, and Slavoj Žižek, among others. More recently, Vivec Chibber has published a very strong critique of the post-colonial project in his book Postcolonial Theory and the Specter of Capital. As such, I am suggesting that this project, already under way, be sustained and intensified. However, I am not interested in simply dismissing 'post' branded theories and critiques. Rather, I am interested in their recalibration, so far as that is possible, such that they can be reoriented toward the critique of capitalism.

3. For Baudrillard (1975), "productivist ideology" can be summed up as follows: "by positing use value as the realm beyond exchange value, all transcendence is locked into this single alternative within the field of value. Qualitative production is already the realm of rational, positive finality; the transformation of nature is the occasion of its objectification as a productive force under the sign of utility (the same is true simultaneously of human labor)" (45). In this way Baudrillard claims that Marxism adheres to a transhistorical metaphysics grounded in the productive utility of labor.

4. See, for example, Baudrillard's (1981b) critique of Hans Magnus Enzensberger.

5. I say 'apparent' because despite Baudrillard's repeated claims that Marxism is no longer relevant, he himself never really stops writing about it. 
6. Baudrillard (1981b) does hint in the direction of what could be considered a form of resistance or revolutionary praxis in terms of "restoring the possibility of response" (170). This is basically a call for a complete rethinking and reconfiguration of the ownership and structure of global communication with reference to an increased degree, or possibility of the exercise of human agency. However, Baudrillard never really develops this abstract and very general line of thought. Instead he takes a deeply nihilistic turn in his subsequent work. Arthur Kroker (1985) claims that this pessimistic/nihilistic turn "is the basic condition for human emancipation as well as for the recovery of the tragic sense of critical theory" (81). But here too, radical critique and human emancipation, as Wendy Brown seems to imply, are grasped in terms of an "exploration" of contemporary experience with no explicit reference to a praxis by which to redress the critique. Furthermore, Kroker's claim that a pessimistic realism is the basic condition for human emancipation seems to go against the empirical 'facts' - Kroker's claim is mere assertion, undergirded neither by reason nor research. The student movements of the 1960 's, for example, took place at a time and in a discursive context when political campaigns still made use of progress narratives such as Lyndon B. Johnson's 'Great Society'. By contrast Eugene Genovese (1976) documents the relative rarity of slave revolts in the seemingly hopeless (from the perspective of American Slaves) American South in his book Roll, Jordon, Roll: the World the Slaves Made. These examples seem to suggest just the opposite of what Kroker claims.

7. Adorno (1984) goes on to say in the same breath that idealism in this sense is "not unlike positive social science which records the products of social processes as ultimate facts to be accepted" (37). Indeed, as a "reification of results", idealism is in a close relationship to positivism with the caveat that one need not take a positive attitude toward those results. Herbert Marcuse (1999) points out that Auguste Comte, one of the forefathers of positivism, "explicitly stated that the term 'positive' by which he designated his philosophy implied educating men to take a positive attitude towards the prevailing state of affairs. Positive philosophy was going to affirm the existing order against those who asserted the need for 'negating' it" (329). Clearly, an idealist position allows one to accept the prevailing state of affairs without taking a positive attitude towards it. One can simply take a resigned attitude towards prevailing affairs. If Comte thought that a positive attitude was necessary to counteract the perceived requirements of negation, Baudrillard shows that there is an alternative one can simply despair of the possibility of negating the prevailing state of affairs. Either way, prevailing affairs remain safe and sound. As such, the key difference between the positivist and the idealist where social change is concerned seems to rest with the allowable range personal dispositions.

8. Ironically this is just what Baudrillard (1975) claims is the problem with historical materialism's approach to "primitive societies" (49-50).
9. Kroker, while recognizing Baudrillard's nihilism and referring to him as a tragic philosopher, sees these qualities as indications of Baudrillard's stark and progressive realism. But he never does address the socially conservative role that tragic art often plays. At any rate, what seems clear is that there is not so much disagreement amongst commentators about the content of Baudrillard's writing as there is concerning Baudrillard's aesthetic - he leaves us in the lurch as to whether he is progressive (hopeful), conservative (pessimistic), or somehow both at once.

10. According to Baudrillard (2010), "caught in a vast Stockholm syndrome, the alienated, the oppressed, and the colonized are siding with the system that holds them hostage. They are now 'annexed,' in the literal sense, prisoners of the 'nexus,' of the network, connected for better or for worse" (37).

11. On this point, according to Baudrillard (2010) "current critical thought continues along its trajectory but it is no longer the critical thought of the Enlightenment and modernity, which had their own object and their own energy. It is merely an epiphenomenon of a world where there is nothing left to analyze in the hopes of subverting it. This thought is no longer current because we are no longer in a 'critical' situation, like the historical domination of capital. We have entered a hegemonic form of total reality, of closed-circuit global power that has even captured the negative. All that is left today is the specific product of this posthumous situation where it no longer has a historical reason to exist or any effectiveness" (40-41).

12. On this last point Baudrillard (2010) claims that "in any event, the question of 'capital' must be reconfigured. ... We must try to pass 'through the looking glass,' beyond the mirror of production" (42). This is an interesting position to take. For here Baudrillard appears to suggest that something very much like ideology is in play where capitalism is concerned. However, this claim certainly fails to avoid contradiction with his earlier claim (see note 11) that there is nothing left to critique, or rather to 'transcend', for lack of a better term.

13. Baudrillard's (1993) rendering of this claim reads as follows: "The end of labour. The end of production. The end of political economy. The end of the signifier/ signified dialectic which facilitates the accumulation of knowledge and meaning, the linear syntagma of cumulative discourse. And at the same time, the end of the exchange-value/use-value dialectic which is the only thing that makes accumulation and social production possible. The end of the linear dimension of discourse. The end of the linear dimension of the commodity. The end of the classical era of the sign. The end of the era of production. It is not the revolution which puts an end to all this, it is capital itself which abolishes the determination of the social according to the means of production, substitutes the structural form for the commodity form of value, and currently controls every aspect of the system's strategy" (8). 
14. In the postscript to Max Horkheimer's (1972) now classic essay "Traditional and Critical Theory," critical theory is defined in terms of its object of analysis "men as producers of their own historical way of life in its totality" - and with reference to its practicality - "the real situations which are the starting-point of science are not regarded simply as data to be verified ... [but also] the intervention of reason in the processes whereby knowledge and its object are constituted." Finally, "critical theory in its concept formation and in all phases of its development very consciously makes its own that concern for the rational organization of human activity which it is its task to illumine and legitimate. For this theory is not concerned only with goals already imposed by existent ways of life, but with men and all their potentialities;" which is to say, finally, that critical theory makes normative claims on the basis of its analytic and practical claims (244-245). If Baudrillard is correct in claiming that we have left behind the social formation in which the form of human praxis analyzed by Marx, abstract labor as the bearer of value, engenders social organization, then he has a strong case to suggest that Marxism no longer grasps one of the elementary requirements for a theory to be critical, "the real situations" in which humans find themselves. However, Baudrillard fails to make a convincing case to show that we have left this form of social organization behind. 15. Baudrillard (2010) differentiates between hegemony and domination as follows: "HEGEMON' means the one who commands, orders, leads and governs (and not the one who dominates and exploits). This brings us back to the literal meaning of the word 'cybernetic' (Kubernetiké, the art of governing). Contrary to domination, a hegemony of world power is no longer a dual, personal or real form of domination, but the domination of networks, of calculation and integral exchange. Domination can be overthrown from the outside. Hegemony can only be inverted or reversed from the inside. Two different, almost contrary paradigms: the paradigm of revolution, transgression, subversion (domination) and the paradigm of inversion, reversion, auto-liquidation (hegemony). They are almost exclusive of each other, because the mechanisms of revolution, of anti-domination, as history demonstrated, can become the impetus or the vector for hegemony" (34). This conceptual differentiation is problematic, mainly as a consequence of its ahistorical approach. However, a critique of Baudrillard's concept of 'hegemony' is beyond the purview of this analysis.

16. Baudrillard (1975) phrases his rejection of Marxism in the following way: "The super-ideology of the sign and the general operationalization of the signifier everywhere sanctioned today by the new master disciplines of structural linguistics, semiology, information theory, and cybernetics - has replaced good old political economy as the theoretical basis of the system. This new ideological structure, that plays on the hieroglyphs of the code, is much more illegible than that which played on productive energy. This manipulation, that plays on the faculty of producing meaning and difference, is more radical than that which plays on labour power" (122).

17. This claim bears significant similarity to Bertell Ollman's (1976) argument that Marx subscribes to a philosophy of "internal relations" (Ch. 3).

\section{References}

Adorno, T. W. (1984). Against Epistemology: A Metacritique. Studies in Husserl and the Phenomenological Antinomies. Cambridge, Mass.: The MIT Press.

Baudrillard, J. (1975). The Mirror of Production. (M. Poster, Trans.). St. Louis: Telos Press Publishing.

Baudrillard, J. (1981a). "Beyond Use Value." In For a Critique of the Political Economy of the Sign. St. Louis, Mo: Telos Press.

Baudrillard, J. (1981b). "Requiem for the Media." In For a Critique of the Political Economy of the Sign. St. Louis, Mo: Telos Press.

Baudrillard, J. (1983). Simulations. Los Angeles: Semiotext(e), Inc.

Baudrillard, J. (1993). Symbolic Exchange and Death. London: SAGE Publications.

Baudrillard, J. (2010). “From Domination to Hegemony." In The Agony of Power. Los Angeles: Semiotexte.
Brown, W. (1995). "The Mirror of Pornography." In States of Injury: Power and Freedom in Late Modernity. New Jersey: Princeton University Press.

Coulter, G. (2011). "Jean Baudrillard's Karl Marx - Productivist Ideology, And The Future of the Left." Fast Capitalism, 8(2).

Dyer-Witheford, N. (1999). Cyber-Marx: Cycles and Circuits of Struggle in High-Technology Capitalism. Chicago: University of Illinois Press.

Foucault, M. (2010). “The Discourse on Language.” In The Archaeology of Knowledge. New York: Vintage Books.

Genovese, E. D. (1976). Roll, Jordan, Roll: The World the Slaves Made. Vintage Books.

Hall, S. (2003). "Marx's Notes on Method: A "Reading” of the “1857 Introduction."” Cultural Studies, 17(2), 113-149. 
Harvey, D. (1989). The Condition of Postmodernity. San Francisco: Wiley-Blackwell.

Horkheimer, M. (1972). "Postscript: Traditional and Critical Theory." In Critical Theory: Selected Essays. New York: Continuum International Publishing Group.

Kellner, D. (2006). "Jean Baudrillard After Modernity: Provocations on a Provocateur and Challenger." International Journal of Baudrillard Studies, 3(1).

Kellner, D. (n.d.). Boundaries and Borderlines: Reflections on Jean Baudrillard and Critical Theory. Retrieved April 22, 2013, from http://pages.gseis.ucla.edu/faculty/kellner/Illumina\%20 Folder/kell2.htm

Kroker, A. (1985). "Baudrillard's Marx." Theory, Culture and Society, 2(3).

Marcuse, H. (1999). Reason and Revolution: Hegel and the Rise of Social Theory. Amherst, NY.: Humanity Books.

Marx, K., \& Engels, F. (1978). "Manifesto of the Communist Party." In The Marx-Engels Reader (2nd Revised \& enlarged). New York: W. W. Norton \& Company.
Ollman, B. (1976). Alienation: Marx's Conception of Man in Capitalist Society. New York: Cambridge University Press.

Postone, M. (1980). "Anti-Semitism and National Socialism: Notes on the German Reaction to "Holocaust."” New German Critique, (19), 97.

Postone, M. (1996). Time, Labor, and Social Domination: A Reinterpretation of Marx's Critical Theory. New York: Cambridge University Press.

Postone, M. (1998). "Rethinking Marx (in a Post-Marxist World).” In C. Camic (Ed.), Reclaiming the Sociological Classics: The State of the Scholarship. Malden, MA.: Wiley.

Shakespeare, W. (1993). “The Tragedy of MacBeth.” In The Yale Shakespeare. New York: Barnes \& Noble Books.

Zizek, S. (2010). Living In The End Times. New York: Verso Press USA. 
